Снежана Д. САМАРЏИЈА*

Универзитет у Београду

Филолошки факултет
Оригинални научни рад

Примљен: 16. 10. 2018.

Прихваћен: 14. 02. 2019.

\title{
ПАВЛЕ ПОПОВИЋ О УСМЕНОЈ ПРОЗИ
}

Усмена проза није у средишту Поповићевих изучавања српске, југословенске и светске књижевности. Ипак, тај сегмент његовог научног опуса може се пратити кроз три повезана тока: класификација народних приповедака; оцена збирки; компаративно истраживање мотива из српског фолклора и писане литературе. Издваја се и сажет, али важан Поповићев програм прикупљања и издавања прозне грађе. ${ }^{1}$

Кључне речи: Павле Поповић, народне приповетке, класификација, збирке, компаративни приступ.

Од краја шездесетих година 19. века када су Стојан Новаковић и Ватрослав Јагић у историје српске и хрватске литературе укључили и усмено стваралаштво, сви писци шире заснованих систематизација националне књижевности освртали су се и на фолклорну баштину. Књижевноисторијске синтезе су махом биле састављане као школски приручници или извод из предавања. ${ }^{2}$ Тако је 1909. и Павле Поповић започео предговор Прегледа сpnске книжевности:

Књига ова представља већим делом извод из предавања која сам држао на Великој Школи и Универзитету последњих пет година. Она је писана да онима који воле и проучавају нашу књижевност послужи као кратак преглед њен и, уколико краткоћа допушта, као подлога за њихов рад на науци (Поповић 1931: V).

У историји српске књижевности и науке о књижевности можда ниједна књига сличног типа и концепције није извршила тако далекосежне утицаје. Наредних деценија штампана су издања Прегледа, са библиографијом или

\footnotetext{
*markosoft@gmail.com

${ }^{1}$ Студија је део пројекта Српско усмено стваралаштво у интеркултурном коду (Институт за књижевност и уметност у Београду), који финансира Министарство РС.

${ }^{2}$ На то су указивали и поднаслови: „за грађанске и више девојачке школе”, ,за ученике средњих школа”, „за народ”, „за учитељске приправнике” и сл. Самарџија 2004: 321-329.
} 
без ње. Поповићеве закључке дуго су понављали аутори педагошких штива, а били су ослонац и при научним испитивањима појединих периода и тема.

\section{Народна проза}

Надахнуто нагласивши старину и естетске домете народне књижевности, ${ }^{3}$ Поповић је највише простора дао епици, ${ }^{4}$ али је прегледно представио и прозу. Ипак, већ се у предговору оградио:

Познато је да питање о класификацији народних приповедака још није решено како ваља; овде је учињена класификација по карактеру приповедака и лицима која у њима раде. Она обухвата све врсте приповедака (Поповић 1931: IX).

„У овом послу” потражио је мишљења Тихомира Ђорђевића и Јиржија Поливке (Поповић 1931: ХІІ). Повезујући савремене термине (бајка, новела, анегдота) са Вуковим одредницама, Поповић је, на први поглед поделу доследно засновао по Вуковим критеријумима из 1853. ${ }^{5}$ Но, док је Вук истакао однос једног типа фантастике према реалистичности, Поповић нарочит значај даје опозицији озбиљно : шаљиво. ${ }^{6}$ Али, одмах запажа како се ове две „врсте” не могу „увек јасно разликовати међу собом” (Поповић 1931: 91). Тиме је, на другачији начин, предочио лаконску Вукову констатацију о постојању приповедака „на међи”.

Покушавајући да успостави „систем” у усменој прози, Поповић је пратио мотиве и ликове, због чега је његов приступ био привидно кохерентан. Примарно полазиште је „угрозило” категорију усмене новеле, представљене у обе „врсте”. Басне су изједначене са причама о животињама, док су недоречене разлике између анегдоте и шаљиве приче дуго утицале на приступе овим жанровима. ${ }^{7}$ Изоставио је форме које Вук у рукопису Живота и обичаја народа српског (Караџић 1969) обухвата одредницама: „вјеровања ствари којијех нема” (митолошка и демонолошка предања) и „о постанку гдјекојих ствари" (етиолошка и есхатолошка предања). Иначе, Поповић појам предање

\footnotetext{
3 „Дубоко под књижевним слојевима српскога народа и ван општега тока писане књижевности, створила се и усменим путем очувала једна анонимна књижевност, поетска и прозна, јака, силна, неоцењиве лепоте, једна од најлепших, које српска књижевност има да покаже”. Поповић 1931: 49.

${ }^{4}$ Лирска поезија (52-55), Епска поезија (55-91) Проза (91-110). Према деветом издању Поповић 1931.

${ }^{5}$ Мада је већ 1818. предочио поделу народних приповедака (Караџић 1966: IX), Вук је тек у предговору Српским народним приповијеткама поновио те критеријуме: „Наше народне приче или приповијетке готово се могу раздијелити на мушке и на женске, као и пјесме. Женске су приповијетке оне у којима се приповиједају којекаква чудеса, што не може бити (и по свој прилици само ће за њих бити ријеч гатка, њемачки (Märchen); а мушке су оне у којима нема чудеса, него оно што се приповиједа рекао би човјек да је заиста могло бити. Многе су мушке приповијетке смијешне и шаљиве. Мушке приповијетке опет би се могле раздијелити на дугачке и на кратке [...] има и приповиједака које су између женскијех мушкијех” (Караџић 1988: 45).

${ }^{6}$ В. прилог на крају овог текста.

${ }^{7}$ В: Милошевић-Ђорђевић 1987, 2000; Златковић 2007: 18-28; Самарџија 2011: 201-271.
} 
користи у најширем значењу - традиције (Popović 1918: 67). Руковођен лепим грађанским манирима, није споменуо „по већој части срамотне” умотворине (Караџић 1988а). Однос према том сегменту баштине јасно је изрекао при осуди записа Радована Добросављевића. Под снажним утицајима Поповићевих погледа на књижевност и фолклор, обредно-смеховна сфера традицијске културе почела је у српској науци да се истражује тек с краја 20. века. ${ }^{8}$

По узору на епске тематске кругове Поповић је саставио „групе и циклусе” приповедака, премда исти критеријум није могао применити на све облике. Легенде, басне и анегдоте делио је по категорији јунака. Обриси „биографија” остали су међусобно неусклађени, зато што је сваки типски лик условљен поетиком жанра, често зависи и од сижејног контекста, ${ }^{9}$ а исти мотиви и црте везују се за различито именоване актере.

Већ по броју забележених варијаната тешко је ускладити и „групе” унутар истог жанра из Поповићеве поделе. Примера ради, за корпус српске грађе, коју је Поповић изврсно и непосредно познавао, нису карактеристични модели о грабанцијашу, Ленори, Али Баби, Риђобрадом. Круг прича о Међедовићу или о Дивљану неупоредиво је ужи од обиља варијација о немуштом језику, пасторкама, змији младожењи итд. Притом, Поповић није издвојио нпр. бајке о змајеборцу или чудесно зачетом јунаку, мада су далеко бројније у српској грађи од нпр. типа Мачак у чизмама.

Недостаци мотивског полазишта испољили су се при представљању басне, „озбиљне” и „шаљиве” новеле. Поповић не наводи заступљене обраде о путовању животиња или више пута превареном вуку. Иако је скроман круг новела посвећен опклади у верност жене или драму језика, Поповић издваја тај „циклус”, јер му је био занимљив због других разлога. Из класификације су искључене често вариране новелистичке ситуације о надлагивању и глупим поступцима (нарочито жена).

Ипак, с обзиром на то да су жанровске особености, макар и на овакав начин, први пут засебно наговештене кроз приступе српској традицији, није случајно што се Поповићева подела понављала у приручницима, уџбеницима и антологијама. Иако је В. Чајкановић 1927. и $1929 .{ }^{10}$ применио другачије решење, оно није потиснуло Поповићеву поделу. Поповићево представљање фолклорног приповедног материјала било је доминантно током 20. века, а

\footnotetext{
${ }^{8}$ Иванић 1984; Еротско 2006; Карановић-Јокић 2009.

${ }^{9}$ Као лик басне и приче о животињама вук означава снагу крволока, али у појединим тематским круговима испољава глупост и тада тријумфује потенцијална жртва. Слична измена карактеризације својствена је и актерима шаљивих прича. Типска грамзивост или неукост попова изостаје при вербалном суочавању са хоџом; за Насрадина су везани бројни мотиви и разне особине, од виспрености до неразумних поступака.

${ }^{10}$ Позивајући се на Арнеову класификацију из 1910, Чајкановић је издвојио: приче о животињама, бајке, новеле, шаљиве приче (први део) и скаске, легенде, веровања, примитивне приче (други део) (Чајкановић 1927: XIII). Његова антологија обухвата: 1. приче о животињама и басне, 2. бајке, 3. приповетке мушке, 4. приповетке кратке, већином шаљиве, 5. скаске, 6. легенде, 7. веровања (Чајкановић 1929: V-VIII).
} 
испољило се и на страницама модерније конципираног универзитетског уџбеника В. Латковића. ${ }^{11}$

По завршетку Великог рата и оснивању Краљевства Срба, Хрвата и Словенаца, затим Краљевине Југославије, у оновременом духу „јединства” Поповић је саставио преглед Југословенске књижевности (Николић 2009: 267). Пето поглавље, Пред новим временом, чинила су два сегмента: Југословенска мисао и Народна поезија. ${ }^{12}$ Дуалистичко полазиште открива деоба на поезију (лирску и епску) и прозу (приповетке, пословице и загонетке), као и при груписању прича на: „дуже и кратке, озбиљне и шаљиве, мушке и женске, опште и локалне" (Поповић 1918: 67). Због обрада бројних мотива „истока и запада” приповетке су, по Поповићевом суду, „важне за упоредну науку о фолклору".

\section{Мотиви}

Након митолошке школе браће Грим, која је имала своје заговорнике и на јужнословенским просторима, Бенфејеву миграциону теорију прихватили су највиђенији српски и хрватски научници (Милошевић-Ђорђевић 1979: 495-500). Поповић није дао предност ниједном од ових приступа, јер су га више од извора мотива занимале њихове обраде у усменој и писаној књижевности.

Малу монографију је 1905. посветио једном типу бајки о прогоњеној девојци. Узор му је био Сишеријев рад из 1884, а та становишта и поделу применио је при излагању сижеа литерарних текстова и усмених варијаната. ${ }^{13}$ Прозним обрадама придружене су и поједине песме. Студија илуструје Поповићева интересовања, правце тумачења књижевности, обавештеност и - статус међу савременицима. Анонимни критичар усудио се да замери што

\footnotetext{
${ }^{11}$ Иако је Латковић дао књижевноисторијски увид у токове сабирања и изучавања народних приповедака, његова подела је вид компромиса између приступа Павла Поповића и прецизнијег одређења усмених жанрова: 1. приче о животињама и басне, 2. бајка, 3. скаска и легенда, 4. новела, 5. шаљива причица и ратничко патријархална анегдота (Латковић 1975: 77-142). Примера ради, уопштена типологија бајки усмерена је ка набрајању кругова о: зетовима животињама, ослобађању царске кћери, змији младожењи, ђаволу, вилама, Усуду и суђеницама, захвалном мртвацу, дивовима, патуљцима, немуштом језику; копању блага, Али-баби, женидби сиромаха принцезом, о милостивом солдату, Ћели; о мајци/сестри крвници, прогоњеним пасторкама, злој жени итд. Латковић је и у осталим прозним жанровима набрајао кругове варијаната на основу мотива, тј. приповедног типа и/или типских ликова.

12 Поповић је у Југословенској књижевности представио: лирске песме (55-56), епске песме (дуги и кратки стих, подела на кругове, постанак, старији записи, европска интересовања, 56-67) (Поповић 1918).

${ }^{13}$ Hermann Suchier, Oeuvres poétiques de Remi sire de Beanmanoir, Paris, 1884. Поповић се детаљно задржао на писаним обрадама, делећи их по мотивацији радње (тј. да ли се у делокругу прогониоца налази отац или маћеха). Први тип се односио на Живот од Оливе хћере Јулијана ћесара, а други на Миракуле славне деве Марије и Чудеса пресвете Богородице. Обраде у српској и јужнословенској усменој грађи представио је Поповић наводећи богат круг варијаната. Придржавао се основне поделе, али је издвојио више подтипова из обе групе: I) 1. Олива, 2. Манекина, 3. Царица са звездом на челу, 4. Бакарна коза, 5. Бог чува праведнога; II) 1. Верзија Миракула - Зла маћеха, 2. Верзија Чудеса - Бог не заборавља правих, 3. О грофовој жени и диии.
} 
Поповић није укључио више примера из хрватске традиције (Аноним 1905: 67-68). Јован Радонић је представио Поповићева истраживања, без коментара (Радоњић 1906: 109-111), као и Фран Илешић (1906: 121). Светислав Стефановић је, међутим, упутио више примедби поводом Поповићевих извора, типологије и излагања (Стефановић 1906). Но, пре почетка било какве научне полемике, коначну реч дао је сам Павле Поповић, опширно демантујући свога критичара (Поповић 1907). ${ }^{14}$

Поповић се враћао поређењу мотива народних приповедака са литерарним обрадама. Представио је Стеријину једночинку Превара за прева$p y$, указујући на „књижевне” верзије и усмене варијанте, од којих је најпознатија из Врчевићевог корпуса, Каматник и харачлија. Повод за слична разматрања дао му је „случај” приповетке Ивана Павловића Оно ће јарко суние проказати. Књижевна јавност је Павловића осудила због плагијата, иако се правдао како је само прерадио мотив народне приче (из живота) о скривеном злочину и разоткривању убице. Поповић је, бранећи Павловића, истакао да у „фолклорној књижевности [...] има више пута оваквих слагања [...] Код више чувених светских писаца има каткада мотива који су врло слични или потпуно једнаки онима у нашим народним приповеткама" (Поповић 2000: 28).

Низом огледа потврдио је такав закључак. Мотиве из српских и јужнословенских усмених обрада поредио је са Шекспировим драмама (Млетачки трговац, Цимбелин, Магбет). Издвојио је двадесето поглавље Волтеровог Задига и предочио сродности са усменим варијантама и верзијама из писаних споменика. Детаљно је изложио Биргерову баладу о Ленори и фолклорне обраде мотива о повратку умрлог вереника/брата. Из Мопасановиг опуса одабрао је легенду о ортаклуку ђавола и Арханђела Михајла и упоредио је са српском верзијом мотива, везаног за Светог Саву.

„У времену када фолклорна истраживања крче себи пут, Поповић са завидном акрибичношћу уводи српску народну приповетку у европску породицу варијаната. Са изванредним познавањем целокупне литературе он се на њу надовезује својим истраживањима српске и јужнословенске грађе из прве руке" (Милошевић-Ђорђевић 2000а: 131-132). О томе сведочи и преглед збирки и примери из тематских кругова о којима пише, расути по периодици (Коло, Босанска вила, Караиић, Кића). Некада су из рукописа (попут Циганских приповедака Т. Р. Ђорђевића) или су из збирки које Поповић није укључио у књижевноисторијски осврт. Такав је случај са једним записом из Српског венца Тодора Влајића, или из корпуса хрватских зборника (М. Ваљавца, М. Стојановића, Р. Ф. Плола Хердвигова, Р. Строхала), македонске, бугарске, словеначке грађе.

Мада се није експлицитно определио за Бенфејеву миграциону теорију, Поповић сматра да су се из Индије приповетке преносиле усменим и писа-

${ }^{14}$ Стефановић је другом приликом предочио варијанте арапских, бугарских и руских приповедака, а посебно се задржао на обради персијске приче Историја Репсиме, у арапској и турској књижевности, традицији Курда и европских народа. Сматрао је да су и западноевропски и оријентални утицаји подједнако важни за српску приповедну грађу (Стефановић 1908). 
ним путем. Његово трагање за најстаријим споменицима у којима су поједини модели обрађени не подразумева само један ток „генезе” интернационалних мотива или „општих приповедака”. Према Поповићевом суду оба процеса су равноправно могла водити до тих сличности, било да је мотив из писане књижевности ушао у усмени фонд или је преузиман из усменог казивања добио литерарне обраде (Поповић 2000: 57).

\section{О збиркама}

Збирке народних приповедака Поповић је сажето и приказао, ${ }^{15}$ уз критичке напомене о естетским дометима, а повод су биле Шаљиве српске народне приповетке Јоаникија Памучине. Том приликом није испољио искључивост, својствену Ћоровићу или Војиславу Јовановић, али ни толеранцију какву је имао Чајкановић када је оцењивао вредности штампаног и рукописног приповедног материјала. ${ }^{16}$ Невеликог обима, али значајна за историју српске фолклористике, студија је предочила основне циљеве књижевне критике, која је захваљујући браћи Поповић добила маха и особена „поетичка правила" у српској култури (Палавестра 2008). Поповић се осврнуо и на допринос Ватрослава Јагића, а део закључака из Јагићевог чланка понавља у завршним разматрањима.

Без прецизних библиографских података Поповић је представио резултате Вукових савременика и следбеника, придржавајући се своје најопштије поделе - на озбиљне и шаљиве приповетке. Први сегмент чланка обухватио је збирке: Атанасија Николића, Јована Војиновића, Bosanske narodne pripovjedke фрањеваца из Ђакова, Ђорђа Стефановића Којанова, Димитрија Алексића, Косте Ристића и Васе Лончарског, Радована Добросављевића, Владимира Красића и Андре Глигоријевића. Засебно су предочене збирке шаљивих прича: Вука Врчевића, Милана Станића, репертоар слепог гуслара Рада Рапајића из записа Манојла Бубала Кордунаша, збирчице Николе Кукића, Луке Грђића Бјелокосића и Спасоја Ђурића.

Поповићеве уопштене формулације не говоре много о садржини представљеног корпуса. Иако је поновио Вукове замерке, битно је ублажио Вуков строг суд о збиркама Атанасија Николића. Јер, како Поповић истиче, ту има „и врло лепих страна”, док су скоро све приче „оригиналне и нове, лепе,

${ }^{15}$ Прву библиографију збирки српских и хрватских народних приповедака (десет наслова) објавио је В. Јагић, наводећи и периодичне публикације, чији су бројеви доносили текстове народних прича: Даница, Вила, Млада Србадија, Босански пријатељ, Коло, Српско-далматински магазин (Јагић 1876: 267-269). Тај Јагићев мали попис збирки поновио је Иван Радетић, као напомену у Pregledu hrvatske tradicionalne književnosti (Радетић 1879: 44-45). Оба податка навео је В. Ћоровић када је састављао допуну Поповићеве библиографије (Ћоровић 1905: 304-307). До Другог светског рата још једном је објављена (непотпуна) библиографија збирки „народне прозе”, а обухватала је пословице и загонетке (Аноним 1934: 335-337). Поповић је осврт на сабирање и штампање народних приповедака објавио у Српском књижевном гласнику (1903, IX, 308-315), да би уз пригодне измене текст придружио огледима Из књижевности.

16 Ћоровић 1905: 378-386; Јовановић 1932; Чајкановић 1927. 
често по својим мотивима врло карактеристичне и значајне” (Поповић 2000: 6). Мада је тешко утврдити смисао категорија оригиналног, новог, лепог и карактеристичног, нарочито у фолклору, овакве квлитете наводио је Поповић и уз коментаре о још понекој збирци.

И негативне оцене Поповић је формулисао уопштено. Додуше, издвајао је примере лошег језика и стила. С правом је приметио како се у записима Ђорђа Којанова „осећа тон из старих рђавих романа превађаних по подлисцима наших новина”, док су учестале и морализаторске примесе (Поповић 2000: 7). Замерке због „рђавог књижевног стила” упутио је и Андри Глигоријевићу, зато што „прекраја народне приповетке и даје им књижевну боју" (Поповић 2000: 9-10). Најоштрије критике изрекао је Поповић о стилу и приређивању записа Димитрија Алексића и Радована Добросављевића. Добросављевићу је нарочито замерио што је у збирку укључио и „четири порнографске приповетке које су далеко од тога да буду ма у ком погледу интересантне а које су, уосталом, могле бити мање драстично написане" (Поповић 2000: 8). ${ }^{17}$ Ови ставови одлично испољавају лични афинитет и однос критичара према приређивању народних приповедака. Очито, Поповић не замера записивачима што (усмени) текст мењају, већ што то не чине према Вуковим мерилима избора варијаната и начина „намештања” речи. Према суду Павла Поповића међу набројаним књижицама готово да и нема узорног издања, нарочито када изостану важни подаци о казивачима, месту и околностима бележења.

Слични недостаци прате и преглед збирки шаљивих народних прича. Заправо, афирмативан суд Поповић је изрекао само поводом (непрецизно наведеног) корпуса Вука Врчевића и сабирачких прегнућа Милана Станића. Грађу осталих записивча оценио је као „безначајне приповетке”, од којих већина „нису бог зна како ни лепе, ни карактеристичне, ни нове, ни лепо писане” или су сами записивачи уносили „моралне појмове” и „новинарске рефлексије" (Поповић 2000: 12-13).

За историју српске фолклористике изузетно је драгоцен завршни сегмент овог огледа. Указујући на пропусте, Поповић је дефинисао и особена усмерења при сабирању, штампању и истраживањима усмених прича. Поред тога што је сматрао како приповетке нису довољно сабиране, он је, као и Јагић пре њега, констатовао да су приповетке „расуте [...] по разним листовим и календарима, каткада старим и тешко приступачним”. Тим поводом набраја периодичне публикације, чија су годишта доносила и приповедну грађу (Летопис Матице српске, Вила, Матица, Караџић, Босанска вила, Српско-далматински магазин, Даница, Стражилово, Просвјета, Луча, календари). Изводећи статистичке податке о броју текстова, Поповић наглашава

\footnotetext{
17 Од двадесет жанровски различитих прича из збирке Р. Добросављевића, Поповић није удостојио ни навођење наслова „порнографских” варијаната. Две шаљиве новеле, једна обрада на међи вица и шаљиве приче и две шаљиве приче варирају мотиве неверне жене и двосмислене изразе који се односе на полне односе (Несрећа, Наивност детета, Зидање воденице, Напад на утврђење), а у једном случају и содомију (Тако њима треба). Р. Добросављевић, Приповетке из српског народа. Београд: Штампарија М. Јовановића, 1895/1896, бр. 3, 4, 7, стр. 91-93, 93-95.
} 
потребу издавања тог материјала, као и рукописне грађе. Корпус би требало објавити у едицијама попут „Књига за народ” Матице српске или мостарске „Мале библиотеке”. Такође, указује на нужност објављивања тематских збирки, а такви ,засебни кругови” могли би се везати за прозне варијанте о Светом Сави или Марку Краљевићу (Поповић 2000: 14).

Следећи циљ у овом малом „програму” подразумева теренска бележења, тим пре што нема довољно сабране грађе из „свих крајева српских”. Нарочито је важно да се приповетке за објављивање приреде према „књижевним условима". За тај посао Поповићу је узор Вукова збирка, заправо тип стилизације какав су примењивали и браћа Грим.

Будућа издања, сматра Поповић, морала би бити опремљена и пригодним научним апаратом, по узору на стране публикације. Прилози би садржали: паралеле из националне традиције, указивање на интернационалне мотиве и литературу. Поповић наглашава неопходност научног апарата при састављању збирки народних приповедака, чак и када су део популарних едиција. Поводом овог последњег закључка изречена су и супротна мишљења. Иначе поштујући Поповићев приступ народој књижевности, Тихомир Остојић се у приказу Поповићеве књиге Из књижевности задржао на чланку о збиркама. Једино неслагање исказао је поводом институције која би требало да систематски приреди приповедни материјал. ${ }^{18}$

Ауторитет Павла Поповића у научним круговима потврдиле су деценије с почетка 20. века. Мада су преокупације и даље биле највише усмерене ка епској поезији, однос према народној прози може се посматрати и као реализација задатака из Поповићевог чланка.

\section{Поповићев „програм” посвећен народним причама}

И остали проучаваоци кретали су се између два рата сигурним Поповићевим путем. Испитивани су поједини приповедни типови и/или обраде интернационалних мотива у европској књижевности и српским усменим варијантама. Владимир Ћоровић је писао критичке напомене о старим и новим збиркама, допунио је Поповићев осврт потпуним библиографским подацима, а бавио се и компаративним истраживањима. У чланку о изворима приповедних модела и везама усмене и писане речи, позива се на Поповићеву студију о девојци без руку. Ћоровић наводи писана дела као могућа изворишта и других типова: о Алкести, Полифему, Марији са Лопуда (Ћоровић 1908: 15-41). И другом приликом слично представља мотиве: о избавиоцу, несрећним љубавницима, повратку мужа на свадбу своје жене, реци која тражи људску жртву, о чудесном пореклу, Јудити, о вечитом Жиду (Ћоровић 1907a: 286-288).

18 „Г. Поповић исказује жељу да којегде разасуте народне приповетке прибере и среди Матица српска у Кьигама за народ или издавачи мостарске Мале библиотеке. Не слажем се с тим предлогом. Академија наука треба да се лати тога посла и да изда критично издања свега материјала који је досад скупљен и који би се, на позив Академије, још скупио” (Остојић 1906/1979: 244). 
Сима Тројановић задржава се на кругу варијаната о захвалности покојника (Тројановић 1909: 108-110).

И у годинама након Великог рата приповедна грађа представља се по узорима која је поставио Павле Поповић. Драгиша Лапчевић пише о Шекспиру и нашим народним умотворинама (Лапчевић 1920: 489-496). Андра Гавриловић посветио је студију српским причама о Фаусту (Гавриловић 1923: 258-265). Павле Стевановић истражује тематске кругове о човеку који се продао ђаволу (Стевановић 1934), а у периодици излазе прикази тог огледа. ${ }^{19}$ И Веселин Чајкановић, из свог угла, разматра круг приповедака о човеку који превари смрт или ђавола (Чајкановић 1939: 142-149). На страницама Книжевног севера излази синтеза Добривоја Алимпића посвећена народним приповеткама. Уз податаке о митолошкој, миграционој и антрополошкој теорији, Алимпић сажима приступ Павла Поповића. Позивајући се на Поповићеве радове представља „циклусе” српских приповедака: Усуд, Пепељуга, девојка без руку, четири ковчега, о Млекарици, Соломону, Тамном вилајету, међеду, свињи и лисици (Алимпић 1934, Х: 189-196).

Поповићеви савременици следили су још један од његових циљева. Срета Стојковић је објавио збирку народних приповедака о Марку Краљевићу, а касније збирку песама и прича о Марку (Стојковић 1913, 1922). Уз указивање на изворе, Владимир Ћоровић је саставио сличан тематски зборник Свети Сава у народном предағу (Ћоровић 1927). Најтеже је, свакако, било испунити онај Поповићев оправдан захтев о примени научног апарата при састављању збирки народних приповедака. Мада је за овај период карактеристично штампање већег броја антологија, само је Веселин Чајкановић уз изборе из рукописне и штампане грађе давао детаљне напомене о варијантама, појединим мотивима и научној литератури (Чајкановић 1927, 1929). Најмање је систематски прикупљан нов материјал и такво стање испољило се у српској фолклористици готово до наших дана. После Другог светског рата, Поповићево дело остало је познато академским круговима, док су истраживања усмене прозе била у сенци изучавања епског песништва.

О Поповићевој посвећености књижевности и његовом поимању особеног научног синкретизма симболично сведоче и Прилози за књижевност, језик, историју и фолклор. Часопис, који је Поповић покренуо 1921, пратиле су бројне тешкоће, али је доживео скоро цео век, што се ретко догађа и у бољим условима за развој националних научних дисциплина. Још једном треба нагласити и важност Поповићевог разматрања усменог стваралаштва као саставног чиниоца националне, али и светске традиције, културе и уметности. И, на крају, мада чини тек мањи сегмент Поповићевог научног опуса, однос према народним причама је незаобилазан за сваку озбиљнију књижевноисторијску синтезу. А део његовог програма посвећеног фолклорној прози још увек чека неко срећније време не би ли се остварио.

${ }^{19}$ В. Новаковић 1934-1935: 827-829; Младеновић 1935: 98-107; Барић 1936-1937: 185-199. 
Класификација народних приповедака у Прегледу српске књижевности Павла Поповића

\begin{tabular}{|c|c|c|c|}
\hline \multicolumn{4}{|c|}{ ОЗБИЉНЕ НАРОДНЕ ПРИПОВЕТКЕ „врсте” } \\
\hline $\begin{array}{l}\text { 1. „којекаква чудеса } \\
\text { што не може бити” } \\
\text { гатке, бајке, } \\
\text { женске приповетке }\end{array}$ & $\begin{array}{l}\text { 2. „нема чудеса ... } \\
\text { заиста (је) могло бити” } \\
\text { мушке приповетке, } \\
\text { приповетке, новеле }\end{array}$ & $\begin{array}{l}\text { 3. „мушке или женске” } \\
\text { везане за „личности } \\
\text { (библијске, историјске) } \\
\text { и места” } \\
\text { легенде, скаске, кажее }\end{array}$ & $\begin{array}{l}\text { 4. „говоре и раде } \\
\text { животиње и мрт- } \\
\text { ве ствари" } \\
\text { басне }\end{array}$ \\
\hline „групе и циклуси” & „гр. и циклуси” & „групе и циклуси” & „гр. и циклуси” \\
\hline $\begin{array}{l}\text { 1) Баш-Челик; } \\
\text { 2) Немушти језик; } \\
\text { 3) Мачак у чизмама, } \\
\text { 4) Змија } \\
\text { младожења; } \\
\text { 5) Анђео и } \\
\text { пустињак; } \\
\text { 6) Усуд; 7) Ђаво и } \\
\text { његов шегрт; } \\
\text { 8) о } \\
\text { грабанцијашима; } \\
\text { 9) Дивљан;10) } \\
\text { Захвални мртвац; } \\
\text { 11) Ленора; 12) Али } \\
\text { Баба и четрдесет } \\
\text { разбојника;13) Пепе- } \\
\text { љуга (Цар хтео кћер } \\
\text { да узме; Девојка } \\
\text { без руку); 14) } \\
\text { Риђобради; } \\
\text { 15) Алкеста. }\end{array}$ & $\begin{array}{l}\text { 1) Опклада (у верност } \\
\text { жене) } \\
\text { 2) Драм језика } \\
\text { 3) Воденичар и његов } \\
\text { мачак }\end{array}$ & $\begin{array}{l}\text { 1. О личностима: 1) } \\
\text { старозаветним (Адам, } \\
\text { Ева, Ноје, Соломон, } \\
\text { Јеремија; 2) новоза- } \\
\text { ветним (Богородица, } \\
\text { Христ, Св. Петар и Св. } \\
\text { Павле) } \\
\text { 2. 1) историјским } \\
\text { и легендарним } \\
\text { (цареви Тројан, } \\
\text { Дукљан, Александар, } \\
\text { Константин, } \\
\text { Мухамед, краљь } \\
\text { Матија, Сибињанин } \\
\text { Јанко) 2) из српске } \\
\text { историје (о Св. Сави, } \\
\text { Краљевићу Марку, Св. } \\
\text { Симеуну, Дечанском, } \\
\text { цару Душану, } \\
\text { Мрњавчевићима, кнезу } \\
\text { Лазару, кнегињи Мили- } \\
\text { ци, Милошу Обилићу, } \\
\text { Стефану Високом, } \\
\text { Јерини, Змај деспоту } \\
\text { Вуку итд) } \\
\text { 3. о местима } \\
\text {-тумачење: } \\
\text { 1) имена (етимолошки); } \\
\text { 2) постанка; 3) } \\
\text { знаменитости }\end{array}$ & $\begin{array}{l}\text { 1. Човек и змија } \\
\text { 2. Во и миш } \\
\text { 3. Срна и срндаћ } \\
\text { 4. Лисица и } \\
\text { грожђе } \\
\text { 5. Вук, лисица и } \\
\text { гавран } \\
\text { 6. Медвед, свиња } \\
\text { и лисица } \\
\text { 7. о магарцу } \\
\text { 8. Зечеви и жабе } \\
\text { 9. Зец и корњача }\end{array}$ \\
\hline \multicolumn{4}{|c|}{$\begin{array}{l}\text { ШАљИВЕ НАРОДНЕ ПРИПОВЕТКЕ „све су мушке тј. у њима се прича оно } \\
\text { 'што је заиста могло бити” „врсте” }\end{array}$} \\
\hline \multicolumn{2}{|c|}{$\begin{array}{l}\text { „праве приповетке, иавиве новеле” } \\
\text { садрже „серију авантура” }\end{array}$} & \multicolumn{2}{|c|}{$\begin{array}{l}\text { „,анегдоте, причице” } \\
\text { садрже само по један мали случај, досетку, } \\
\text { згодну реч ...објашњене пословице или } \\
\text { развијене питалице” }\end{array}$} \\
\hline \multicolumn{2}{|c|}{$\begin{array}{l}\text { 1. Досетљива девојка } \\
\text { 2. Досетљиви дечак } \\
\text { 3. Поп у трњу } \\
\text { 4. Луди Пера и турски цар }\end{array}$} & \multicolumn{2}{|c|}{$\begin{array}{l}\text { 1. о „народним шаљивцима”: 1) Ћоси; 2) } \\
\text { Насрадин-хоџи; 3) Хери; 4) Вуку Дојчевићу; } \\
\text { 5) Вуку Злоћевићу; 6) Баја Џори; 2. „о } \\
\text { појединим сталежима”: 1) поповима; 2) } \\
\text { калуђерима; 3) хоџама, фратрима; 3. } \\
\text { женама; 4. о „братствима и племенима” } \\
\text { подругачице; 5. о народностима (Турци, } \\
\text { Јевреји, Немци, Енглези, Цигани) }\end{array}$} \\
\hline
\end{tabular}




\section{ЛИТЕРАТУРА}

Алимпић 1934: Д. Алимпић, „Неколико мисли о односу наше народне прозе и старе књижевности", у: Књижевни север, X, 7-10, 189-196.

Аноним 1905: П. Поповић: Приповетка о девојци без руку (...), Савременик, I, 67-68.

Аноним 1936-1937: „Важније збирке наше народне прозе”, у: Кюижевни север, 1934, X, 11, 335-337.

Барић 1934: Х. Барић, Стевановић Павле, „Приповетка о човеку који се продао ђаволу", у: Наставни вјесник, XLV, 185-199.

Гавриловић 1923: А. Гавриловић, „Српске приче о Фаусту”, у: Гласник професорског друштва, III, 258-265.

Еротско у фолклору Словена, пр. Д. Ајдачић. Београд: Стубови културе, 2006.

Златковић 2007: И. Златковић Први српски устанак у говору и у твору, Београд: Институт за књижевност и уметност.

Иванић 1984: D. Ivanić, Mrsne priče (erotska, sodomijska i skatološka narodna proza, prikupio, izdao i komentarisao Fridrih. S. Kraus), Beograd: Prosveta.

Илешић 1906: F. Ilešić. Приповетка о девојци без руку. Студија из српске и југословенске књижевности, Београд, 1095. Ljubljanski zvon, XXVI, 121.

Јагић - Келер 1876 - 1877 - 1881: V. Jagić - R. Köhler. Aus dem Südslavichen Märchenschatz. Archiv für Slavische Philologie, Berlin, I: 270-269; II: 614.641; V: 17-70.

Јовановић 1932: В. Јовановић, Красићеви плагиати. Српски књижевни гласник (СКГ), $\mathrm{CCCV}, 2$.

Карановић-Јокић 2009: 3. Карановић, Ј. Јокић, Смеховно и еротско у српској народној култури и поезији, Нови Сад: Филозофски факултет.

Караџић 1966: В. С. Караџић, Српски рјечник 1818, Сабрана дела В. Караџића, II, пр. П. Ивић, Београд: Просвета.

Караџић 1969: В. С. Караџић, Етнографски списи. О Црној Гори, пр. Г. Добрашиновић - М. Филиповић, Београд: Просвета.

Караџић 1988: В. С. Караџић, Српске народне приповијетке, Сабрана дела В. Караџића, III, пр. М. Пантић, Београд: Просвета.

Караџић 1988а: В. С. Караџић, Преписка, I. Сабрана дела В. Караџића, ХХ, пр. Г. Добрашиновић, Београд: Просвета.

Лапчевић 1920: Д. Лапчевић, „Шекспир и наше народне умотворине”, у: Mucao, II, 2, 489-496.

Латковић 1976: В. Латковић, Народна књижевност, Београд: Научна књига.

Младеновић 1935: Ж. Младеновић, Стевановић, Павле, Приповетка о човеку који се продао ђаволу, Београд, 1934, у: Летопис Матиие српске, CVIII, 344, 98-107.

Милошевић-Ђорђевић 1979: Н. Милошевић-Ђорђевић, „Теорије о настанку народних приповедака у нашој науци 19. века", у: Научни састанак слависта у Вукове дане, Београд: МСЦ, IX: 495-500. 
Милошевић-Ђорђевић 1981: Н. Милошевић-Ђорђевић, „Преглед прозних облика наше усмене књижевности", у: Кюижевна историја, Београд, XIV, 53: 35-42.

Милошевић-Ђорђевић 2000: Н. Милошевић-Ђорђевић, Од бајке до изреке. Београд: Друштво за српски језик и књижевност Србије.

Милошевић-Ђорђевић 2000а: Н. Милошевић-Ђорђевић. Павле Поповић и изучавање народне књижевности, поговор: Павле Поповић, Народна књижевност. Сабрана дела П. Поповића III. Београд: Завод за уџбенике: 119-126, 127-133.

Николић 2009: Н. Николић, Концепција српске и југословенске књижевности Павла Поповића, у: Зборник Матище српске за књижевност и језик, LVII/2: 267-295.

Новаковић 1934: Б. Новаковић, Др. П. Стевановић, Приповетка о човеку који се продао ђаволу, Београд, 1934. Гласник Југословенског професорског друштва, XV, 827-829.

Остојић 1979: Т. Остојић, П. Поповић. Из књижевности. Летопис Матице српске, 1906, CCXXXVI/2: 97-103. Према: Павле Поповић и историјска критика, пр. П. Палавестра. Нови Сад- Београд. Матица српска - Институт за књижевност и уметност: 238-245.

Палавестра 1979: П. Палавестра, Павле Поповић и историјска критика у српској књижевности: Павле Поповић и историјска критика, пр. П. Палавестра. Нови Сад - Београд: Матица српска - Институт за књижевност и уметност: 7-46.

Палавестра 2008: П. Палавестра, Историја српске књижевне критике 1768 2007, I-II. Нови Сад: Матица српска.

Пантић 2000: М. Пантић, „Преглед српске књижевности” Павла Поповића: П. Поповић, Преглед српске кюижевности. Сабрана дела П. Поповића, I. Београд: Завод за уџбенике: 177-225.

Поповић 1903: П. Поповић, Из наших народних приповедака. Српски књижевни гласник, IX, 5, 353-363.

Поповић 1904: П. Поповић, Из наших народних приповедака, II. СКГ, XII, 6 : 1061-1068.

Поповић 1905: П. Поповић, Приповетка о девојизи без руку, Београд: СКА.

Поповић 1907: П. Поповић, Светислав Стефановић, Приповетка о девојци без руку (реферат у Делу, 1906, св. за децембар), СКГ, XVIII, 9, 685-691; 10. 770-776; 12, 936-949.

Поповић 1912: П. Поповић, Из наших народних приповедака, III. Шекспиров Цимбелин и народне Приповетке, СКГ, 1913, XXX, 9, 668-676.

Поповић 1913: П. Поповић, Из наших народних приповедака, IV. Биргер и наше приповетке. СКГ, $\mathrm{XXX}, 11,835-843$.

Поповић 1906/1926²: П. Поповић, Из књижевности, I. Београд.

Поповић 1919: П. Поповић, Из књижевности, II. Београд.

Поповић 1931: П. Поповић, Преглед српске кюижевности, Београд, 1912; 1931 (девето издање). 
Поповић 1999: P. Popović, Jugoslovenska književnost. (Književnost Srba, Hrvata i Slovenaca), Cambridge: University Press, 1918, 1919. ${ }^{2}$ Сабрана дела П. Поповића, IX, пр. Н. Љубинковић, Београд: Завод за уџбенике.

Поповић 2000: П. Поповић, Народна књижевност, у: Сабрана дела П. Поповића, III, пр. Н. Милошевић-Ђорђевић. Београд: Завод за уџбенике.

Радонић 1906: Ј. Радонић, Приповетка о девојци без руку, у: Летопис Матиие српске, LXXIX, 235: 109-111.

Самарџија 2004: С. Самарџија, „Усмена проза у историјама српске књижевности 19. и 20. века", Научни састанак слависта у Вукове дане, Београд: МСЦ, XXXII/2: 321-329.

Самарџија 2011: С. Самарџија, Облищи усмене прозе. Београд: Службени гласник.

Св. Сава у народним причама. Из збирке народних приповедака Новице Шаулића, Београд, 1934.

Стевановић 1934: П. Стевановић, Приповетка о човеку који се продао ђаволу, Београд.

Стефановић 1908: С. Стефановић, „Прилози студији српских народних приповедака", у: Бранково коло, XIV.

Стојковић 1913: С. Стојковић, Марко Краљевић, збирка народних приповедака, Београд.

Стојковић 1922: С. Стојковић, Краљевић Марко. Збирка од 220 народних песама и 90 приповедака. Нови Сад: Друштво Свети Сава.

Тројановић 1909: С. Тројановић, Нешто о народној причи, уопће и посебно: Захвалност покојникова, у: Босанска вила, XXIV, 108-110.

Ћоровић 1905: В. Ћоровић, Прилог библиографији српских народних приповјегака, у: СКГ, XV, 4: 304-307.

Ћоровић 1905а: В. Ћоровић, „О Врчевићевој подјели српских народних шаљивих приповиједака", у: СКГ, XV, 5: 378-384.

Ћоровић 1905б: В. Ћоровић, Јеремија Обрад, Караџић: Српске народне приповијетке у: СКГ, XV, 5: 384-390.

Ћоровић 1907: В. Ћоровић, „Неки општи мотиви у српским народним приповијеткама", у: Босанска вила, XXII: 286-288.

Ћоровић 1908: В. Ћоровић, „О неким врелима српских народних приповедака", у: Летопис Матице српске, LXXXI, 250: 15-41.

Ћоровић 1927: В. Ћоровић, Свети Сава у народном предању, спремио В. Ћоровић. Београд: Задужбина Радојице Ј. Ђурића.

Чајкановић 1927: В. Чајкановић, Српске народне приповетке, Београд: СКА.

Чајкановић 1929. В. Чајкановић, Српске народне приповетке, Београд: Књижарница Рајковића и Чуковића.

Чајкановић 1939: В. Чајкановић, „Прича о човеку који је преварио смрт”, Прилози за књижевност, језик, историју и фолклор, XIX, 1-2: 142, 149. 
Snežana Samardžija

\title{
PAVLE POPOVIC ON ORAL PROSE
}

\begin{abstract}
(Summary)
Oral prose is not the focus of Popovic's studies of Serbian, Yugoslav, and World literature. Yet this segment of his work can be traced through three related streams: the classification of folk tales; assessment of collections; comparative study of motifs from Serbian folklore and written literature. Popovic's program of collecting and publishing prose material is also very important.
\end{abstract}

